$9^{\text {th }}$ IUCN Academy of Environmental Law Colloquium

Mpkweni, South Africa, 3-8 July 2011

Water and the Law: Towards Sustainability

Sustainability, governance and water management in New Zealand

Dated: 5 July 2011 


\section{SUSTAINABILITY, GOVERNANCE AND WATER MANAGEMENT IN NEW ZEALAND}

\section{Trevor Daya-Winterbottom}

Senior Lecturer, Centre for Environmental Resources and Energy Law, Faculty of Law, University of Waikato*

\section{BACKGROUND}

New Zealand is a "pluvial society". ${ }^{1}$ The common perception before 1997 was that there were no serious issues regarding freshwater in New Zealand compared with other jurisdictions, notwithstanding the fact that irrigation had doubled to 500,000ha during the period 1985 to 1997. However, freshwater allocation was set to become a significant issue in the future. ${ }^{2}$ By 2003 problems in the Waitaki catchment of the South Island brought matters sharply into focus as competition between productive users became fierce and increasingly litigious, and problems were occuring regarding allocation between competing irrigation applications and between irrigation and hydro electric power schemes. ${ }^{3}$

BA (Hons) in Law (LJMU), Diplôme de IIDH (Strasbourg), MA in Environmental Law (DMU), FRSA, FRGS, MRSNZ, Legal Associate RTPI, Barrister (Lincoln's Inn \& New Zealand). Member, Resource Management Law Association of New Zealand. Founding General Editor, Resource Management Theory \& Practice. Director, Ecologic Foundation. Member, New Zealand Centre for Environmental Law. Guest Professor, Department of Public International Law, Faculty of Law, University of Ghent, Belgium.

1 Attributed to Rt Hon Sir Geoffrey Palmer SC, President, New Zealand Law Commission.

2 Arthur, B Rivers - Sharing finite resources, $5^{\text {th }}$ Annual Resource Management Law Association Conference 1997 Queenstown.

3 Milne, $\mathrm{P}$ Allocation of Water between Productive Uses, $11^{\text {th }}$ Annual Resource Management Law Association Conference 2003 Blenheim. 
Subsequently, freshwater allocation has been subject to legislative amendments and litigation before the Supreme Court, and new planning documents at both national and regional level are being developed to guide decision making. Demand for freshwater use has continued to grow "to the point [in many areas] where shortages occur because the spatial and temporal patterns of supply do not match demand patterns", and it is expected that "the majority of the catchments that support New Zealand's main population centres and agricultural production ... [will] be fully allocated by $2012^{\prime \prime}{ }^{4}$

The purpose of this paper is to review the law on restrictions relating to freshwater under the Resource Management Act 1991 (RMA). The paper will focus on the taking and use of water, and current proposals for reform of the water management regime under the RMA.

\section{SUSTAINABLE MANAGEMENT}

The RMA came into force on 1 October 1991. The objective of the statute was "to restate and reform the law relating to the use of land, air, and water". The RMA repealed 59 statutes and provided a new direction for environmental law in New Zealand. Enactment of the RMA was preceded by the Resource Management Law Reform (RMLR) project. In relation to freshwater management the RMLR focused (inter alia) on the preparation of policy statements and plans and the transfer of water permits. The RMLR articulated clearly defined objectives for policy statements and plans while pursuing a voluntary approach to their preparation. For example, the consultation document stated: ${ }^{5}$

4 Bright, J; Rout, R; \& Rouse, H Sustainable Freshwater Management Towards an Improved New Zealand Approach (August 2008) pp1-2. Report prepared for the New Zealand Business Council for Sustainable Development.

5 Ministry for the Environment People, Environment, and Decision Making: the Government's Proposals for Resource Management Law Reform (December 1988), p38. 
Communities have an interest in seeing that allocated water is used efficiently and not wasted. There is good evidence that the current water rights system has not always resulted in water being used most efficiently - once people have a permit, there is no reason for them to be cautious in their use. Even if they conserve water, they cannot transfer the unused portion of their permit to someone else.

Policy statements and plans were to be community led, "based on publicly agreed policy", and define the quantum of water available for use for industry or irrigation and "how much left in the river to maintain its instream values". ${ }^{6}$ Notwithstanding these important functions, the RMLR project envisaged that plans "would only be required where resource conflicts or environmental problems were significant" and justified the cost of preparing, monitoring and reviewing the plan. ${ }^{7}$

Subsequently, the Resource Management Bill was subject to independent review. Key issues identified by the review also focused on the transfer of water permits, in particular, maintaining instream flows and the need for "security of tenure" to underpin the market in tradeable water permits. ${ }^{8}$

\section{Sustainable management}

Sustainable management of natural and physical resources is the overarching, statutory purpose of the RMA. Section 5(2) of the RMA stipulates:

(2) In this Act sustainable management means managing the use, development, and protection of natural and physical resources in a way,

6 Ministry for the Environment People, Environment, and Decision Making: the Government's Proposals for Resource Management Law Reform (December 1988), p38.

7 Ministry for the Environment People, Environment, and Decision Making: the Government's Proposals for Resource Management Law Reform (December 1988), pp37-38.

8 Randerson, AP et al Report of the Review Group on the Resource Management Bill (February 1991), pp95-96. 
or at a rate, which enables people and communities to provide for their social, economic, and cultural wellbeing and for their health and safety while-

a) sustaining the potential of natural and physical resources (excluding minerals) to meet the reasonably foreseeable needs of future generations; and

b) safeguarding the life-supporting capacity of air, water, soil, and ecosystems; and

c) avoiding, remedying, or mitigating any adverse effects of activities on the environment.

"Natural and physical resources" are specifically defined as including water, and "water" is spefically defined as including freshwater (both surface water and ground water) but does not include water "while in any pipe, tank, or cistern". ${ }^{9}$

The statutory purpose is supported by a series of subordinate and nonexhaustive principles that illustrate how sustainable management can be achieved. ${ }^{10}$ Relevant to freshwater management are the preservation of the natural character of lakes and rivers, maintaining and enhancing public access to and along lakes and rivers, and the relationship of Maori with ancestral waters. ${ }^{11}$ Also relevant to freshwater management are kaitiakitanga or guardianship, the ethic of stewardship, the efficient use of natural and physical resources, maintaining and enhancing environmental quality, the finite characteristics of natural and physical resources, protecting the habitat of salmon and trout, the effects of climate change, and the benefits to be derived from renewable energy. ${ }^{12}$

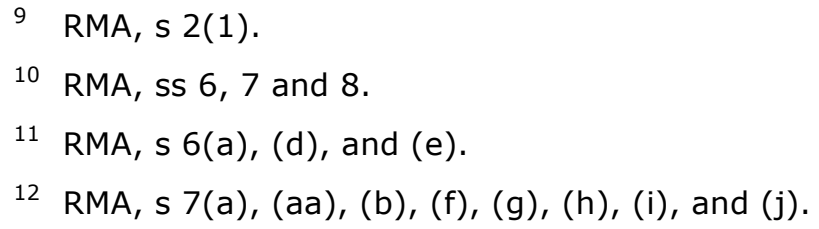


The principles in ss 6 and 7 of the RMA also illustrate the range of competing uses for freshwater in New Zealand. For example, Williamson observed: ${ }^{13}$

The Waikato River is an interesting system in that it is New Zealand's longest river and provides a vast range of uses such as: hydro electricity development through nine hydro electricity dams and associated power stations; cooling water for two geothermal and one thermal power stations; recreational uses including fishing and various boating; cultural values; and municipal and irrigation water supply. In addition, the river acts as a sink for point source contaminant discharges from various industries and diffuse source discharges from agricultural land use.

Initially there was a strong philosophical debate as to whether the extended definition of sustainable management in $s 5(2)$ of the RMA should be read and interpreted in a conjunctive or disjunctive way. Semantic difficulty arose from the central position of the word "while", directly in between the liberal enabling theme and the list of environmental bottom lines in paragraphs (a) to (c). Did the section require balancing between the liberal and environmental themes, or were the environmental bottom lines absolute requirements that must be met in all cases?

The debate was resolved by the Environment Court in North Shore City Council $v$ Auckland Regional Council ${ }^{14}$ where the Court was required to evaluate conflicting considerations regarding the urbanisation of the Okura Estuary, north of Auckland, in the context district plan zoning:

Application of s 5 ... involves consideration of both main elements of s 5 . The method calls for consideration of the aspects in which the propoosal would represent management of natural and physical resources in a way or at a rate which enables people and communities to provide for their

13 Williamson, J Balancing environmental and economic outcomes for agricultural sustainability Annual Resource Management Law Association Conference 2006, p8.

14 [1997] NZRMA 59. 
social, economic and cultural wellbeing, health and safety. It also requires consideration of the respects in which it would not meet the goals described in paras (a), (b) and (c).

The method of applying $s$ then involves an overall broad judgment of whether a proposal would promote the sustainable management of natural and physical resources. That recognises that the Act has a single purpose ... Such a judgment allows for comparison of conflicting considerations and the scale or degree of them, and their relative significance or proportion in the final outcome. ${ }^{15}$

The Court of Appeal subsequently adopted a similar view in Watercare Services Ltd $v$ Minhinnick regarding an enforcement notice appeal where Tipping J stated: ${ }^{16}$

The Court must weigh all the relevant competing considerations and ultimately make a value judgment on behalf of the community as a whole. Such Maori dimension as arises will be important but not decisive even if the subject matter is seen as involving Maori issues. Those issues will usually, as here, intersect with other issues such as health and safety: compare $s 5(2)$ and its definition of sustainable management. Cultural wellbeing, while one of the aspects of section $5(2)$, is accompanied by social and economic wellbeing. While the Maori dimension, whether arising under s 6(e) or otherwise, calls for close and careful consideration, other matters may in the end be found to be more cogent when the Court, as the representative of New Zealand society as a whole, decides whether the subject matter is offensive or objectionable under s 314 . In the end a balanced judgment has to be made.

In the context of the "overall broad judgment" or "balanced judgment" approach to sustainable management adopted in these cases it is

15 [1997] NZRMA 59 at 94.

16 [1998] NZRMA 113 at 124-125 per Tipping J. 
interesting to note the more recent extrajudicial comment by Sheppard regarding sustainable management: ${ }^{17}$

As with other legislation of this generality, applying this criterion depends on the context. For example, applying it to urban activities (new suburbs, shopping centres, supermarkets) may call for balancing of conflicting values. But managing limited natural resources needs a more robust approach.

Sheppard suggested that "a more robust approach" could be founded on the principles in ss 6-8 of the RMA relevant to fresh water management. ${ }^{18}$ Regardless of the approach, Part 2 of the RMA is central to the working of the statute. Policy statements and plans prepared under the RMA are required to promote sustainable management, ${ }^{19}$ and resource consent applications are assessed against the requirements of ss $5,6,7$, and 8 of the RMA. ${ }^{20}$

\section{RESTRICTIONS RELATING TO WATER}

The use and development of natural and physical resources is subject to a series of duties and restrictions that generally require prior authorisation for all activities, except land use activities. For example, s 14(1) of the RMA prevents any person from taking, using, daming, or diverting freshwater unless:

- The activity is expressly allowed as a permitted activity by a rule in the relevant regional plan. ${ }^{21}$

17 Sheppard, DF Reaching sustainable management of fresh water [2011] RMT \& $P 85$ at 87.

18 Sheppard, DF Reaching sustainable management of fresh water [2011] RMT \& P 85 at 87-89.

19 RMA, ss 59, 63(1), and 72.

20 RMA, s 104(1) substituted by s 44 of the Resource Management Amendment Act 2003. Came into force 1 August 2003.

21 RMA, s 14(3)(a). 
- The water is required to be taken or used to meet "reasonable domestic needs", or for stock watering, or for fire fighting activities. $^{22}$

As a result resource consent is required from the relevant regional council to take and use water in all other circumstances. The type of resource consent required and the types of activity for which consent may be required will be governed by the rules in the regional plan. ${ }^{23}$

When deciding applications regional councils must have regard to any actual or potential effects on the environment of allowing the activity, and to any relevant provisions of the applicable planning instruments. ${ }^{24}$ In relation to freshwater, relevant planning instruments include national policy statements, regional policy statements, and regional plans.

\section{The current water management regime}

Any person can apply for a water permit. ${ }^{25}$ Under s 88 of the RMA the application must be made using the prescribed form, and must include an assessment of environmental effects (AEE) prepared in accordance with Schedule 4 of the RMA. ${ }^{26}$ The AEE must be in "such detail as corresponds with the scale and significance of the effects that the activity may have on the environment". ${ }^{27}$ Failure to include an "adequate" AEE in the application may result in the consent authority determining that the application is incomplete, and returning it to the applicant together with written reasons for the determination. ${ }^{28}$ Any determination under s 88(3) must be made within 5 working days after

22 RMA, s 14(3)(b) and (e).

23 RMA, ss 77A, 77B, and 87.

24 RMA, s 104(1)(a) and (b) substituted by s 44 of the Resource Management Amendment Act 2003. Came into force 1 August 2003.

25 RMA, s 88(1).

26 RMA, s 88(2).

27 RMA, s 88(2)(b).

28 RMA, s 88(3). 
the application was filed with the consent authority. Objection and appeal rights are afforded to any aggrieved applicant under ss 357-358 of the RMA. ${ }^{29}$ Where the power under $s$ 88(3) is not exerised the application will be deemed full and complete.

Section $123(d)$ of the RMA provides that a water permit may be granted for a period not exceeding 35 years. Generally, consents are granted for a shorter duration.

Priority is given to existing consent holders under ss 124 and $124 \mathrm{~B}$ of the RMA. Where competing applications are filed to use all or part of the same resource, existing consent holders are given piority over all other applicants and the consent authority is required to determine the renewal application first before determining any other applications. ${ }^{30}$ It is for note that, priority under $s 124 \mathrm{~B}$ of the RMA is procedural rather than substantive. Any renewal application must be filed with the consent authority during the period starting six months before, and ending three months before the permit is due to expire. ${ }^{31}$ When determining any renewal application, the consent authority is allowed to have regard to certain criteria, including, the efficiency of the applicant's use of the water resource, the use of industry good practice by the applicant, and whether any enforcement action (including criminal prosecution) has been taken against the applicant under the RMA. $^{32}$ While a renewal application is being processed, the applicant may continue to operate under the existing water permit until either the consent is granted and any appeals are decided, or until consent is declined and any appeals are decided. ${ }^{33}$

The consent authority may periodically review any consent conditions included on the grant of a water permit under s 128 of the RMA, or in

\footnotetext{
29 RMA, s 88(5).

30 RMA, s 124B(2)

31 RMA, s $124(2)(d)$.

32 RMA, s $124 \mathrm{~B}(4)(\mathrm{c})$.

33 RMA, s 124(3).
} 
times of serious temporary water shortage in the region may issue a direction under s 329 of the RMA that the taking or use of water is to be apportioned, restricted, or suspended. ${ }^{34}$ Water shortage directions may be made for a period of up to 14 days, and may be renewed. ${ }^{35}$

Provision is also made for the transfer of water permits under $\mathrm{s} 136$ of the RMA. Permits for the take and use of water may be transferred to any owner or occupier of the site in respect of which the permit is granted, or may be transferred to another site. ${ }^{36}$ Where a permit is transferred to another site, the other site must be in the same catchment as the original site. ${ }^{37}$ The permit may be transferred upstream or downstream. ${ }^{38}$ The whole or any part of the consent holder's interest in the water permit may be transferred, and the transfer may be permanent or for a limited period. ${ }^{39}$ The transfer must either be expressly allowed as a permitted activity by a rule in the relevant regional plan, or approved by the consent authority after an application has been filed. ${ }^{40}$ Where an application is required under $\mathrm{s}$ 136(4) the application must be made in the prescribed form, and must be determined as if it were an application for resource consent under $\mathrm{s}$ 88 and as if the consent holder is the applicant for consent. ${ }^{41}$ It is for note that, an existing consent holder is not given any priority in relation to the transfer over all other applicants. In over-allocated catchments, the loss of priority may result in the transfer application being declined.

\section{NATIONAL GUIDANCE}

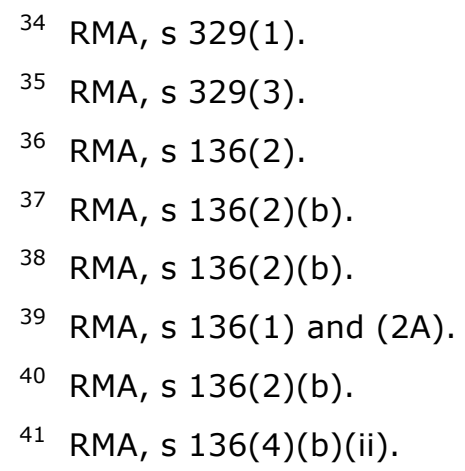


The RMA provides for a hierarchy of standards, policy statements, and plans designed to inform and guide the resource consent process. To date there are no National Environmental Standards (NES) in force relating to freshwater, and the National Policy Statement (NPS) on Freshwater Management only took effect as recently as 1 July 2011. As a result plan preparation by regional councils has taken place in a vacuum and there is no common approach to water management in New Zealand.

To remedy this situation the previous Labour Government established the Sustainable Water Programme of Action (SWPA) in 2003.

The SWPA resulted in the preparation of three planning instruments:

- NPS for Freshwater Management.

- NES for Measurement of Water Takes.

- NES on Ecological Flows and Water Levels.

But slow progress has been made. For example, the NES on Ecological Flows and Water Levels was notified by the previous Minister for the Environment, Hon David Benson-Pope, on 20 March 2008. Submissions have been analysed and it was anticipated that the NES may come into force by the end of 2009, but it now appears increasingly unlikely that the NES will ever be brought into force.

These national planning instruments adopted a cautious approach to harmonising environmental policy and regulation. The NPS adopts a European style "directive" approach by providing a list of matters to be given effect to by regional councils within defined time periods. Drafting of the rules to be included in regional plans is left to the local authorities to determine. As a result there will be variety in terms of the regulatory approaches adopted by different local authorities, and consistent administration of the NPS will be difficult to achieve.

Similarly, different methods are currently used by regional councils to protect in-stream values during low flow events but no attempt was 
made in the NES to adopt a consistent national approach, notwithstanding the focus of the NES on ecological flows and water levels. ${ }^{42}$

As a result the SWPA has been the subject of critical commentary: ${ }^{43}$

First, the management of all water resources suffers from a lack of national policy direction and general absence of nationally identified resource management values. Secondly, effective management of ... freshwater bodies ... is undermined by inadequate scientific information in relation to the nature of the resource, and the cumulative impacts of activities on the resource. Notably, [the regulartory regime has] yet to develop effective management tools for the purpose of dealing with scientific uncertainty. Finally, [the freshwater management regime does not] provide for effective mechanisms for the purpose of prioritisation and efficient allocation of user rights ... Regrettably, the regulatory reforms proposed thus far ... are cautious and unambitious.

Given the eight year policy preparation process from 2003 to 2011, the drafting style adopted by the NPS which depends almost entirely on subordinate action by regional councils, and the long period specified for compliance (31 December 2030) the criticism of the process appears to be justified.

\section{FRESHWATER ALLOCATION}

The RMA was amended in 2005 to provide for the establishment of rules in regional plans to allocate for the taking and use of freshwater. ${ }^{44}$

42 For example, in Canterbury mean annual low flow (MALF) is used to determine allocable flows, whereas in the Waikato the one in five year low flow (Q5) is used to determine allocable flows.

43 Scott, K From the Lakes to the Oceans: Reforming water resource management regimes in New Zealand (2006) 17 Water Law 232 at 244245.

44 RMA, s 30(1)(fa) inserted by $s$ 11(2) of the Resource Management Amendment Act 2005. Came into force 10 August 2005. 
The ability to include rules in regional plans regulating freshwater allocation is circumscribed by the fact that such rules cannot reallocate water from an existing consent holder to another person during the term of that consent. ${ }^{45}$ But regional councils can include rules in a regional plan that reallocate water in "anticipation" of the expiry of existing consents. ${ }^{46}$ When allocating water in anticipation of the expiry of such consents, the rule may allocate: ${ }^{47}$

- All of the resource to the same type of activity; or

- Some of the resource to the same type of activity, and the rest of the resource to other types of activities; or

- Some of the resource to the same type of activity, and the rest of the resource to no type of activity at all.

Rules may also allocate water among competing types of activities. ${ }^{48}$ But rules allocating water cannot affect water required to be taken or used for domestic needs, for stock watering, or for fire fighting activities. $^{49}$ These provisions are beginning to work their way through the plan preparation system. ${ }^{50}$

45 RMA, s 30(4)(a) inserted by s 11(4) of the Resource Management Amendment Act 2005. Came into force 10 August 2005.

46 RMA, s $30(4)(c)$ inserted by s 11(4) of the Resource Management Amendment Act 2005. Came into force 10 August 2005.

47 RMA, s $30(4)(d)$ inserted by s $11(4)$ of the Resource Management Amendment Act 2005. Came into force 10 August 2005.

48 RMA, s $30(4)(e)$ inserted by s 11(4) of the Resource Management Amendment Act 2005. Came into force 10 August 2005.

49 RMA, s $30(4)(f)$ inserted by $s$ 11(4) of the Resource Management Amendment Act 2005. Came into force 10 August 2005.

50 For example, the Waikato Regional Council notified Proposed Waikato Regional Plan: Proposed Variation No. 6 - Water Allocation on 20 October 2006. Submissions closed on 4 December 2006, and submissions were heard by Commissioners during the period December 2007 to March 2008. Following a lengthy period of deliberation the Commissioners recommendations were reported to the Council on 30 October 2008, and appeals have now been lodged with the Environment Court. The appeals were heard by the Environment Court during the period 28 February to 4 August 2011, and the Court has reserved its decision. It is anticipated that 


\section{First come, first served}

In the interim, freshwater allocation is determined by the default rule established in Fleetwing Farms Ltd v Marlborough District Council. ${ }^{51}$ In Fleetwing the Court of Appeal, on further appeal from the Environment Court and the High Court, was required to determine how competing resource consent applications regarding the same resource should be decided.

The case involved two applications for coastal permits to establish mussell farms in the same area of water, where the grant of consent for one proposal would necessarily exclude the other. Resource consent was refused and both applicants lodged appeals with the Environment Court. The Court heard the appeals sequentially in the order in which the appeals were lodged, in accordance with its normal practice. This reversed the order in which the applications were notified and heard by the consent authority.

After considering the scheme of the RMA, the Court of Appeal found that the consent authority was required to decide each application on its merits "without regard" to any competing application. The Court stated: $:^{52}$

The conclusion that the statute requires the council to judge each case on its merits ... accords with the primacy attached to s 5 . If the relevant statutory criteria infused with the underlying objective of sustainable management are met in a particular case there is nothing in the Act to warrant refusing an application on the ground that another applicant would or might meet a higher standard than the Act specifies ... In each case the council must advance the application through to the point of public notification ... It is ... implicit that if another application remains undecided, that does not justify comparing one against the other and

the Court may release its decision in November 2011, but Variation 6 is unlikely to become operative before 2012 .

51 [1997] 3 NZLR 257 (CA).

52 [1997] 3 NZLR 257 at 262 (CA). 
failing to give a timely decision on the first application on its merits without regard to the other.

The Court of Appeal noted that other statutory regimes provided a range of methods for allocating resources between competing applications. For example: ${ }^{53}$

1) provide for a comparative assessment of competing applications;

2) provide for purchase of the entitlement say by tender;

3) provide for a proportional allocation, based, for instance, on the applicant's history in the activity;

4) provide for allocation by lot;

5) proceed on a first come first served basis.

Overturning the previous decisions, the Court of Appeal found that the RMA used the "first come first served" approach to resource allocation between competing applications. The Court held: ${ }^{54}$

... where there are competing applications in respect of the same resource before the council, the council must recognize the priority in time. On appeal the Environment Court sits in the shoes of the council. If it has two such appeals before it, it must in the exercise of that original jurisdiction take account of that earlier priority. Not to do so would run counter to the policy underlying the provisions governing proceedings before a council. It could deprive an appellant whose appeal was filed in time of the priority it previously had.

While concluding that "receipt and/or notification" of an application by the consent authority appeared to be the "critical time" for determing priority between competing applications, the Court of Appeal did not regard its decision as being conclusive for all cases under the RMA.

\footnotetext{
53 [1997] 3 NZLR 257 at 265 (CA).

54 [1997] 3 NZLR 257 at 267 (CA).
} 


\section{Non-derogation from grant and legitimate expectation}

Freshwater allocation came sharply into focus in Aoraki Water Trust $v$ Meridian Energy Ltd. ${ }^{55}$ The background to the case was that Meridian held resource consents relating to its hydro electricity generation scheme that allowed it to dam the natural outflow from Lake Tekapo in the Waitaki catchment, and divert up to 130 cubic metres of water per second into a canal for generation purposes. Aoraki sought resource consent to take up to 15 cubic metres of water per second from the lake for irrigation purposes.

It was clear that allowing Aoraki to take water from the lake would have an adverse effect on Meridian by reducing the available flow. But the law under the RMA was uncertain. Did the consents held by Meridian present "an insuperable obstacle to Aoraki, as a matter of law under the RMA"?

To decide this question the High Court decision in Aoraki considered the nature of resource consents. For example, does the grant of consent confer a privilege or a right on the consent holder?

Under the WSCA the Town and Country Planning Appeal Board had previously found that the grant of a water right did not provide a guarantee for extraction of the volume of water allowed to be taken. The legal effect of granting the water right was simply to render lawful what would otherwise have been unlwaful absent the grant of consent. Subsequently, in Auckland Acclimatisation Society Inc $v$ Sutton Holdings $L t d,{ }^{56}$ the Court of Appeal defined water rights as "privileges".

Based on the previous law Aoraki contended that the legal effect of granting a water permit under the RMA simply conferred a privilege on the consent holder, and not an exclusive right that could be used to prevent other persons from taking or using freshwater from the same

\footnotetext{
55 [2005] NZRMA 251 (HC).

56 [1985] 2 NZLR 94.
} 
resource. Meridian on the other hand contended that its consents were not "privileges" or bare licences, but were "rights" that "could not be derogated from or diminished by issue of a further water permit to a third party". ${ }^{57}$

The High Court was persuaded by the combination of property rights and public law arguments put forward by Meridian. Key matters that influenced the Court's judgment were the requirement in $s 7(b)$ of the RMA to have regard to the efficient use and development of natural and physical resources, and the concession made by Aoraki that allowing it to take water from the lake would "devalue" Meridian's interest in the water. The Court held: ${ }^{58}$

[41] In our judgment, granting a water permit for a particular volume of water over a specified period of time commits the consent authority to that grant in the sense that it is not entitled to deliberately erode the grant unless it is acting pursuant to specific statutory powers. The relevant factors applying in this public law context are similar to those underlying non-derogation from grant. In situations where the consent authority's commitment represents a full allocation of the resource ... the grantee ... must reasonably expect to proceed with full planning and investment on the basis that the consent authority will honour its commitment. Indeed, refusal to recognize that expectation would seriously undermine public confidence in the integrity of water permits ... (Emphasis added)

In reaching this conclusion the High Court relied on the decision of the Court of Appeal in Fleetwing. For example, Robinson has observed: ${ }^{59}$

In particular, the Court accepted Meridian's argument that the grant of procedural priority on a first come, first served basis would be pointless unless it meant that the first permit in time of grant also had priority in terms of the right to use the resource.

57 Robinson, T What's in an Allocation? March 2005 RMJ 21 at 22.

58 [2005] NZRMA 251 at 265 (HC).

59 Robinson, T What's in an Allocation? March 2005 RMJ 21 at 23. 


\section{Sustainable management, gazumping, and integrity}

The Court of Appeal was required to return to the issue of priority between competing applications in Central Plains Water Trust $v$ Ngai Tahu Properties $L t d .^{60}$ In this case Central Plains applied for a water take from the Waimakariri River in the Canterbury region in 2001, but processing of the application was deferred by the consent authority under s 91 of the RMA pending applications for additional consents required in respect of the proposal. Subsequently, in January 2005 Ngai Tahu applied for consent to take a smaller volume of water from the same river which was also deferred pending the reciept of additional applications. The applications for the additional consents were made by Ngai Tahu in August 2005 and by Central Plains in November 2005. The Court was required to determine which application should have priority for notification and hearing. Previously, the Environment Court and the High Court had ruled in favour of Ngai Tahu.

The majority in Central Plains (Baragwanath and Hammond JJ) found that the RMA was silent on the question of priority between competing applications. They also found that Fleetwing had not decided the "stage" at which "priority is achieved", and that this point was open for the Court to decide. The Court focused on the statutory purpose of the RMA: promoting the sustainable management of natural and physical resources. For example, Justice Baragwanath sought to ensure that priority between applications should be decided in a way that will achieve sustainable management: ${ }^{61}$

[59] There is an obvious public interest that the law should not frustrate a proposed development in the course of undergoing the statutory processes. At least where the whole resource being sought is the subject of an application, there should be no risk of a major development being trumped or significantly interfered with by later,

\footnotetext{
60 [2008] NZRMA 200 (CA).

61 [2008] NZRMA 200 (CA) per Baragwanath J.
} 
smaller, simpler inconsistent proposals that are able to be made comprehensively without needing to be processed in stages.

As a result the majority in the Court of Appeal chose to determine priority between applications in a way that would not defeat large, staged projects and prevent them from being "overridden" by smaller projects that, if granted consent, would result in inconsistent resource allocation decisions. This point was emphasised by Justice Hammond who drew an analogy with the "first to file" patent system and the problem of "gazumping": 62

[96] The difficulties of allocation of rights by a filing system can also be seen, much more distantly, in the jurisprudential debate over first-toinvent versus first-to-file in patent systems. One can allocate an "invention" to the first person to actually invent it, or to the first person who files an application for the invention. The United States of America is unique in the world ... in having a first-to-invent system. One of the principal reasons for the United States adopting that system was that a first-to-invent system protects against "gazumping" by later "inventors", who devote their resources to early filing, rather than "true" invention. "Gazumping" is no more attractive in the case of water rights, than in the case of inventions.

[97] ... this priority issue is ... unlikely to be solved by a simplistic bureaucratic yardstick as "first in, first served". Karl Llewellyn once said ... that "sometimes we just need a rule". He was correct in some commercial contexts: once a rule is "known" ... people can negotiate around it. But I doubt very much if this subject area lends itself to that approach. Both legal history and logic may suggest that when the needs of proprietors are known in advance the ideal rule is to allocate water resources in proportion to particular needs. It is only when the proprietors ... are not known in advance that a "fall-back" rule is required. Then, and in that situation, a priority rule can allocate the resource to the first user ... But in fundamental principle, a priority rule should not be the priority rule. (Emphasis added)

62 [2008] NZRMA 200 (CA) per Hammond J. 
Justice Robertson (in the minority) focused on the "integrity" of the decision making process by consent authorities, and the need to ensure that sufficient information is available to inform the process. But all members of the Court were concerned about the lack of any statutory guidance on the question of priority. For example, Robertson J observed: ${ }^{63}$

[126] Who has priority in a given case is a matter of fundamental importance as consent authorities do not become involved in comparison of competing merits when there is more than one application. It is regrettable that Parliament has not, in clear and unequivocal terms, legislated to make plain when an application is considered to have been made, so that the "first come, first served" process can operate with fairness and integrity. The problems of not doing so are vividly illustrated in this case ... (Emphasis added)

As a result the Court of Appeal in Central Plains went further than the Court in Fleetwing. The previous decision had concluded that "receipt and/or notification" of an application by the consent authority appeared to be the "critical time" for determing priority between competing applications. But the Court in Central Plains disected this conclusion, with the majority taking a purposive approach to sustainable management and the pragmatic need for large projects to proceed in stages, whereas the minority focused on the need for "fully" informed decision making.

The Court of Appeal decision in Central Plains seeks to provide "a neat and tidy response" to the practical question as to which application should have priority when consent authorities are required to decide competing applications regarding access to freshwater resources. ${ }^{64}$

63 [2008] NZRMA 200 (CA) per Robertson J dissenting.

64 Whata, C and Minhinnick, D The Issue of Priority Re-emerges August 2008 RMJ 8 at 11. 
But both approaches in Central Plains are not free from difficulty. For example: ${ }^{65}$

There is a level of arbitrariness to both decisions. Both pick winnners based on a particular conception of first in, first served. It is difficult to fault a process which is grounded on ensuring the right information is placed before the decision maker, a point strongly affirmed by the Supreme Court in Discount Brands Ltd $v$ Westfield (New Zealand) Ltd [2005] 2 NZLR 597 ... It might be said that the analogy to intellectual property or property in general is inapt, where rights accrue on lodgement at the appropriate registry office. In this context, substantive decisions need to be made before conferral of substantive rights. Decision makers must make those decisions on a properly informed basis.

The majority approach, however, attempts to provide certainty for applicants while ensuring that adequate information is available to consent authorities to provide the basis for "informed decision making".

Leave to appeal the Court of Appeal decision in Central Plains to the Supreme Court was granted on 24 June 2008. The approved grounds of appeal were: ${ }^{66}$

Is priority as between competing resource consent applications determined by which application is lodged first with the consent authority, or by which is first ready for notification, or by some other test?

Whatever the test, is priority lost by:

A decision of a consent authority under s 91 of the RMA to defer notification of the application pending application for additional consents?

65 Whata, C and Minhinnick, D The Issue of Priority Re-emerges August 2008 RMJ 8 at 11-12.

66 Ngai Tahu Properties Ltd v Central Plains Water Trust [2008] NZSC 49. 
Delay while the applicant makes additional applications required by the consent authority under s 91 ?

The grant of an application to another applicant relating to the same resource? (Emphasis added)

The appeal was heard on 13 and 14 October 2008 and resulted in a 202 page transcript.

\section{Allocation by rule or the exercise of discretion?}

Subsequently, the Supreme Court in Central Plains issued an interim judgment on 26 March 2009. ${ }^{67}$ The Court stated:

[1] At the hearing of this appeal, all counsel took the position that priority as between competing applications under the Resource Management Act 1991 for a finite resource should be determined by a rule. Their submissions were directed to the question of what that rule should be. The Court now wishes to hear argument on the prior question of whether priority should be decided by a rule or through the exercise by consent authorities of a discretion and, if the latter, on what principles should the discretion be exercised. (Emphasis added)

The Supreme Court also stated that a rule based approach to priority was consistent with the Court of Appeal decisions in Fleetwing and Central Plains, and the High Court decision in Geotherm Group Ltd v Waikato Regional Council. But these authorities were only persuasive, and were not binding on the Court. ${ }^{68}$

In Geotherm the High Court was required to consider the question of priority between competing resource consent applications in cases where further information was requested by the consent authority

67 Ngai Tahu Properties Ltd v Central Plains Water Trust [2009] NZSC 24.

${ }^{68}$ Ngai Tahu Properties Ltd $v$ Central Plains Water Trust [2009] NZSC 24 at paragraph [2]. 
under s 92 of the RMA after notification of the applications. Justice Salmon held: 69

[30] Against that background the appropriate stage for consideration of who should have priority on a first come, first served basis, can be determined. It must, in my view, be the stage at which the applications are ready for notification. To pick an earlier date would run the danger of giving priority to an applicant who had filed an inadequate application. To choose a later date, would cause priority to be lost for reasons which could be outside the control of the applicant.

There were also practical considerations in favour of giving priority to the application that was ready for notification first, such as the need to provide certainty for third parties (submitters) and consent authority staff so that they could prepare for the hearing.

\section{Learning from the past, securing the future}

Professor Joseph Sax highlighted the current dilemma in New Zealand regarding priority between competing applications for use of the same freshwater resource. He noted: ${ }^{70}$

It is always the case that any grant of permission to take water diminishes what is available to the next applicant. There are several ways to deal with this dilemma. First, however, it is important to separate what may be called the traffic rule problem from the substantive problem. Traffic rules decide in what order applications will be considered. Substantive rules decide the basis on which applications will be granted. (Emphasis added)

The current dilemma results from the fact while there are "traffic" rules under the RMA to determine the order in which applications should be considered based on "receipt and/or notification", there are no substantive rules under the RMA to determine the basis on which

70 Sax, J Our precious water resources: learing from the past, securing the future [2009] Resource Management Theory \& Practice, p41. 
competing applications should be decided. In the absence of rules in the relevent regional plan, s 104(1) of the RMA provides wide discretion. Substantive rules would provide guidance regarding the exercise of that discretion, and transparency regarding the assessment criteria. For example, Professor Sax outlined a public interest specification approach to "substantive" priority based on Californian and Alaskan statutes that includes criteria such as the: ${ }^{71}$

- Benefit to the applicant.

- Economic effect of the activity.

- Effect on fish and game resources.

- Effect on public health.

- Opportunity cost.

- Harm to other persons.

- Ability of the applicant to complete the project.

- Effect on navigation.

Providing assessment criteria in regional plans to inform the decision making process under s 104(1) of the RMA would not necessarily result in cases such as Central Plains being decided differently, but it would provide consent authorities with objective and transparent criteria as the basis for exercising their discretionary judgment. It should also reduce litigation as the substantive criteria would be certain and known in advance. As a result the interim judgment of the Supreme Court in Central Plains may have identified the key issue: that a substantive rule is required to assist decision making under the RMA. But the question remains whether substantive discertionary assesment criteria for deciding competing applications for the same freshwater resource

71 Sax, J Our precious water resources: learing from the past, securing the future [2009] Resource Management Theory \& Practice, pp42-43. 
should be stated in a common law decision, or should be restated in further RMA reform. The difficulty for the Supreme Court, however, will be whether it can overcome the previous judicial reluctance of the Court of Appeal to contemplate "comparative" assessment of competing applications.

\section{Comparative assessment of competing applications}

It is now a matter of primarily historical significance, but the competition for freshwater resources in the Waitaki catchment highlighted by the resource consent applications made by Aoraki and others provided the catalyst for special legislation to provide for the preparation of a water allocation plan, and the call in of the applications for determination by the Minister for the Environment. The Resource Management (Waitaki Catchment) Bill 2003 as introduced into the House of Representatives provided:

\section{Comparative consideration of applications}

(1) The applications considered under this section must be compared by $-$

(a) first applying the purpose and principles in Part II of the principal Act

(b) then having regard to the economic and social benefits and costs of each use of the water from a national perspective

(2) In this section, national perspective includes the sum of the relevant regional and local social and economic benefits and costs.

Subsequently, concern was expressed about the legitimacy of a Panel of Commissioners deciding the resource consent applications called in by the Minister. As a result the Bill was amended by Supplementary Order Paper 244, and s 42 was deleted and provision was made for the applications to be decided by the relevant consent authorities. ${ }^{72}$ But there was a simple elegance in s 42 that could assist in resolving the

72 Parliamentary Debates (Hansard) Volume 620, p15406 - Resource Management (Waitaki Catchment) Amendment Bill 2003, In Committee, 7 September 2004. 
question of priority between competing applications that seems destined to return before the courts with regularity, unless the "substantive" rule for deciding the basis on which competing applications should be determined is resolved by the Supreme Court or the RMA reform process. It is, however, clear from the commentary by Professor Sax that some element of "comparative consideration" is implicit in the approach adopted by the US jurisdictions to deciding "substantive" priority.

\section{Fleetwing revisited}

Following the issue of the interim judgment by the Supreme Court the Central Plains hearing was due to be resumed in August 2009 but the proceedings were settled by agreement prior to the hearing. ${ }^{73}$ As a result no final decision was issued on the procedural and substantive issues regarding priority. The Court of Appeal was however required to return to these issues to determine the sequel to the Central Plains case in Central Plains Water Trust $v$ Synlait $L t d^{74}$ regarding "competing claims to water from the Rakaia River" south of the Waimakariri River in the Canterbury region.

The primary question before the Court in Synlait was whether priority should be determined by whichever resource consent application "is first ready for notification". The Court focused on the dichotomy between a rule based approach to priority and a discretionary based approach to priority identified by the Supreme Court in the Central Plains interim judgment. The Court identified two broad themes at play: an "efficiency" theme based on Fleetwing and the desirability of avoiding undue delay in the resource consent process, and a second theme based on "sustainable management". While sustainable management as defined by $s 5$ provides the overarching statutory

\footnotetext{
73 For general discussion of Central Plains and Synlait see: Crawford, J and Moynihan, R Fleetwing Revisited August 2009 RMJ 11; and Inns, J Central Plains Water Trust $v$ Ngai Tahu Properties Ltd - An Opportunity Missed or a Sideshow Averted? November 2009 RMJ 20.

74 CA544/2008 and CA588/2008 [2009] NZCA 609.
} 
purpose of the RMA and "suffuses the whole statute", the Court noted with caution that all resource consent applications could not be decided "de novo" as this would "defeat" efficiency of process and "run counter" to the hierarchy of policy statements and plans prepared under the RMA. ${ }^{75}$ Justice Baragwanath giving the reasons for the judgment stated:

[84] We have concluded that two different priorities need to be separated. One is priority of hearing. That is a matter of vital public concern because without it there can be no order in dealing with the essentials of life - land, water, air and the rest. Other legal systems have found it necessary to do more than provide principles and to stipulate rules so people can manage their affairs; Justinian's Pandects provide one example of many. The other is priority of merits.

[85] For the former, the Fleetwing/Ngai Tahu rule provides the starting point for all cases. Often, as those cases show, unless there is substantial merit-based reason to reject the earlier application, it will also prove to be the finishing point. But Ngai Tahu recognises that what is a valuable presumptive factor - the date of first filing - cannot invariably determine the case. It acknowledges certain exceptions.

Based on the scheme of the statute and the "need to achieve procedural efficiency" the Court concluded that the question of priority should be determined in favour of the first person to file a complete resource consent application, and held that priority of hearing should not be "displaced" by directions under s 91 or further information requests under $s 92 .{ }^{76}$ The Court stated: ${ }^{77}$

Absent a finding of material delay we are not prepared to treat the s 91 hold as altering the presumptive hearing priority of the first to file.

75 [2009] NZCA 609 at paragraph [78].

76 [2009] NZCA 609 at paragraphs [92] and [86].

77 [2009] NZCA 609 at paragraph [94]. 
The Synlait decision confirms that the first person to make a "complete application is presumtively entitled to the first hearing", ${ }^{78}$ and that the second person to make a competing application regarding the same resource may only participate in resource consent application process as a submitter. The consent authority, however, retains wide discretion to refuse the grant of resource consent based on the merits of the application, to grant consent for part of the proposed activity, to reserve judgment until the second application has been heard or to adjourn the hearing part way through the process. As a result the decision recognises the "limits of the Fleetwing/Ngai Tahu rule", ${ }^{79}$ but the Court emphasised that the rule remained firmly in place and that it did not provide justification for delay while the consent authority investigates whether granting consent will promote sustainable management. The appeal by Central Plains was allowed.

Subsequently, on 31 March 2010 the Supreme Court granted Synlait leave to appeal against the Court of Appeal decision of the Court of Appeal. The approved ground of appeal was:

... how priority is to be determined as between competing applications under the Resource Management Act 1991 for a finite resource.

Similar to Central Plains, however, the appeal was settled by agreement before being heard by the Supreme Court. The Supreme Court does not appear to be fully convinced by the pragmatism of the Fleetwing approach, and remains open to exploring the question of whether priority should be decided by the exercise of discretion guided by appropriate assessment criteria. For example, Milne and Conway observed that: ${ }^{80}$

The most recent Central Plains decision provides more clarity about consent application priority than the earlier Ngai Tahu decision.

78 [2009] NZCA 609 at paragraph [89].

79 [2009] NZCA 609 at paragraph [91].

80 Milne, $\mathrm{P}$ and Conway, M Implementing the law on consent application priority - powers and potential pitfalls April 2010 RMJ 1 at 7. 
However, there remain a number of uncertainties and a need for statutory amendment to make Parliament's intentions clear and provide the necessary tools for consent authorities. The more fundamental issue about whether sustainable management is well served by a "first in, first served" approach is a matter for further debate and one the Government is considering this year.

However, they noted that the Synlait decision is not problem free. In particular, Milne and Conway identifed four specific issues arising from the Court of Appeal decision. First, when will an application be considered full and complete? Here they noted that local authority staff will retain a discretion under $s$ 88(3) of the RMA to determine whether the information included in the AEE provides sufficient detail "as corresponds with the scale and significance of the effects that the acivity may have on the environment". ${ }^{81}$ Second, the presumption in favour of priority of hearing as opposed to priority of substantive merits. Here Milne and Conway noted the obvious point that priority of hearing does not necessarily mean that consent will be granted in all cases, as the applicant will still need to establish that granting consent will promote the sustainable management of natural and physical resources as required by $s$ of the RMA. While the RMA does not provide for comparative assessment of competing applications, Milne and Conway noted that where the first application is notified subsequent applicants will have the right to make submissions and be heard on the question of whether the first application satisfies the test in $s .^{82}$ Third, they noted that while implicit in the Court of Appeal decision, the RMA provides no express power for the consent authority to delay processing subsequent lower priority applications. ${ }^{83}$ Fourth, they questioned what may amount to unreasonable delay. This matter is important given the Court's finding that priority may be lost where unreasonable delay in processing an application is caused by the

81 Milne, $\mathrm{P}$ and Conway, M Implementing the law on consent application priority - powers and potential pitfalls April 2010 RMJ 1 at 5.

82 Milne, $\mathrm{P}$ and Conway, M Implementing the law on consent application priority - powers and potential pitfalls April 2010 RMJ 1 at 6.

83 Milne, $\mathrm{P}$ and Conway, M Implementing the law on consent application priority - powers and potential pitfalls April 2010 RMJ 1 at 6. 
applicant. Milne and Conway approached this question in a pragmatic way and opined that local authorities could either set reasonable time frames for the applicant to complete the process by filing other necessary applications or providing further information, or set the application down for hearing regardless of whether the applicant is ready to proceed. ${ }^{84}$

Crawford and Moynihan addressed the dichotomy between rules and discretion when commenting on the Court of Appeal decision in Central Plains and took a broader view on how the law may develop in the future, they opined that: ${ }^{85}$

The momentum is gathering in support of a merits-based discretionary approach to water allocation at the consenting stage.

Sheppard also reached a similar, principled, conclusion following a careful analysis of the case law. Based firmly on interpretation of the principles in ss 6-8 of the RMA relevant to fresh water management, he observed that: ${ }^{86}$

... priority to use a resource ... call for management of fresh water to be strongly influenced by concepts other than who applied first ...

... applying the "first come, first served" policy alone would, as Justice Hammond said, be problematic if competing claims for water are to be decided on individual applications scattered in time and locality. Justice Baragwanath was surely right in assigning heavy weight to the high policy of ensuring sustainable management in assessing what priority regime accords with Parliament's policy.

However, Sheppard considered that regional plans were well placed to provide the necessary policy guidance required to achieve sustainable

84 Milne, $\mathrm{P}$ and Conway, M Implementing the law on consent application priority - powers and potential pitfalls April 2010 RMJ 1 at 7.

85 Crawford, R and Moynihan, R Fleetwing Revisited August 2009 RMJ 11 at 13.

86 Sheppard, DF Reaching sustainable management of fresh water [2011] RMT \& P 85 at 100 . 
management, and he concluded emphatically that further statutory amendment of the RMA was not required. ${ }^{87}$

\section{The influence of international water law}

Crawford and Moynihan also questioned whether strict "adherence to a rule based approach" will promote sustainable management or comply with New Zealand's international obligations. ${ }^{88}$ More specifically, they observed: ${ }^{89}$

It is worth reflecting on the fact that New Zealand adopted Agenda 21 in 1992. Agenda 21 is the most significant international soft law agreement on freshwater management. It requires states to take steps to ensure that they manage and allocate freshwater in a sustainable, efficient and equitable manner. Agenda 21 has resulted in a substantial body of international principles on sustainable development of water, has clearly encouraged policy innovation within nations and has served as a vehicle for sharing information and ideas. A system which allows competing applications to be evaluated on the merits is much closer to the system originally envisaged by Agenda 21 and confirmed by subsequent international reports and UN resolutions. New Zealand would do well to tap into the wealth of experience from nations who have been dealing with water scarcity for the last 20 years.

Subsequently, Moynihan analysed Agenda 21 in greater depth and identified four key principles that apply to New Zealand, namely, integrated water resource management, devolution, water resources assessment, and water as an economic good. She concluded that the RMA gives effect to the the first two principles, but noted that the RMA does not provide for the continual assessment of the quantity and quality of water resources in order to determine their availability, and that it does not make adequate provision for water pricing or trading.

87 Sheppard, DF Reaching sustainable management of fresh water [2011] RMT \& P 85 at $101-102$

88 Crawford, R and Moynihan, R Fleetwing Revisited August 2009 RMJ 11 at 13.

89 Crawford, R and Moynihan, R Fleetwing Revisited August 2009 RMJ 11 at 13. 
While noting the slow progress made by the SWPA, Moynihan observed in relation to the New Start for Freshwater launched by the current National Government that: ${ }^{90}$

Although this new direction appears to be based upon principles which have existed internationally for 20 years, it is pleasing that we are making progress.

Overall, Moynihan concluded that the first in, first served rule selected by the Court of Appeal in Fleetwing as the default rule for determing priority under the RMA presents a significant compliance issue for New Zealand in relation to its Agenda 21 obligations. $^{91}$

From an international perspective Wouters and Moynihan noted that the RMA provides no practical guidance for regional councils regarding water allocation, and concluded that the Canterbury experience "demonstrates that, under conditions of scarcity, the framework is incapable of enabling the sustainable management of water". ${ }^{92}$ They also noted that the "prolific volume of litigation" demonstrates "the need for more certainty surrounding the priority test where there are several applications competing over one finite resource". Building on its role as a party to a number of multi-lateral environmental agreements, Wouters and Moynihan also considered that New Zealand could learn from international legal practice where a variety of dispute settlement methods are used in the context of water resources, including, "negotiation, enquiry, mediation, conciliation, arbitration, judicial settlement, and resort to regional agencies or alternative arrangements". ${ }^{93}$ On a more positive note, they also considered that

90 Moynihan, R International Law and Policy on Water Allocation: Does New Zealand comply? November 2009 RMJ 5 at 9.

91 Moynihan, R International Law and Policy on Water Allocation: Does New Zealand comply? November 2009 RMJ 5 at 7; Wouters, P and Moynihan, R Sustainable freshwater management - Where's the magic? [2011] RMT \& P 70 at 82.

92 Wouters, P and Moynihan, R Sustainable freshwater management - Where's the magic? [2011] RMT \& P 70 at 82.

93 Wouters, $\mathrm{P}$ and Moynihan, R Sustainable freshwater management - Where's the magic? [2011] RMT \& P 70 at 78. 
New Zealand may in return have the ability to influence international legal practice, if the current government's reform programme produces concrete results. ${ }^{94}$ At a more practical level, Wouters and Moynihan observed that there were both threats and opportunites for the New Zealand economy "through trade in water intensive commodities", 95 which provides a further impetus for the policy debate regarding fresh water management to be resolved in a sustainable way.

\section{A FRESH START FOR FRESH WATER}

The current Minister for the Environment, Hon Dr Nick Smith, announced a new agenda for fresh water reform in June 2009. Components of the reform agenda include, marrying "successful economic and environmental policies" in a "new paradigm", a "collaborative approach to environmental governance", greater leadership from central government, a clearer focus on "more specific goals", and effective involvement by Maori in the policy debate. ${ }^{96}$ The

94 Wouters, P and Moynihan, R Sustainable freshwater management - Where's the magic? [2011] RMT \& P 70 at 79-80.

95 Wouters, $\mathrm{P}$ and Moynihan, R Sustainable freshwater management - Where's the magic? [2011] RMT \& P 70 at 73 and 74-75.

96 Smith, N Agenda for Fresh Water Reform, Speech, Environmental Defence Society Conference, 8 June 2009. The inclusion of effective involvement of Maori in the policy debate regarding fresh water resources is a significant development. See: Ruru, J Indigenous People's and freshwater: rights to govern? November 2009 RMJ 10 at 13 where she notes the National-led coalition government's acknowledgement that Maori present both a challenge and an opportunity, but observes that the key point is the need for dialogue between Maori and all segments of New Zealand society. This aspect of the policy debate regarding fresh water resources will be dynamic as a result of Treaty settlements. For example, the Waikato-Tainui settlement provides for co-management of the Waikato River based on a vision and strategy that has been included by statute in the regional policy statement and referenced in the Proposed Waikato Regional Plan: Proposed Variation 6 - Water Allocation. See: Te Aho, L Negotiating co-management of the Waikato River November 2009 RMJ 14 at 18 where she notes "Though the settlement is a negotiated compromise ... co-management provides an opportunity to bring to an end a 'paradigm of exclusion' through the development of a spirit of co-operation and mutual regard towards a single purpose, to restore and protect the health and well-being of the Waikato River for future generations": November 2009 RMJ 14 at 18. However, providing for more effective Maori involvement in the fresh water policy debate remains the one aspect of the current National Government's reform agenda that has not gained any traction. See for example: Ruru, J Maori legal rights to water: Ownership, management, or just consultation? 
speech signaled a policy shift away from the SWPA, and formed part of a broader agenda for environmental reform going beyond the Resource Management (Simplifying and Streamlining) Amendment Act 2009. Dr Smith put matters in context: ${ }^{97}$

... New Zealand has been experiencing a boom in intensification of agriculture since 1990. The area of irrigated land has more than doubled albeit that is still only $5 \%$ of our total agricultural land and a third of that which could be irrigated. Nitrogen fertiliser use has increased by more than five fold and phosphate fertiliser use has more than doubled. This intensification has seen agricultural production and export receipts increase by $50 \%$ and kept our balance of payments deficit in check.

But the Minister also drew attention to the fact that in certain areas fresh water resources were under pressure due to over-abstraction and deteriorating water quality, and indicated that "difficult balancing decisions between environment, economic potential and other values" would need to be taken to address these issues. ${ }^{98}$ To progess matters, $\mathrm{Dr}$ Smith announced that the Land and Water Forum, a nongovernmental mulit-party stakeholder group, would be asked to report on the challenges facing New Zealand and make recommendations for

[2011] RMT \& P 119 which draws attention to the Crown's ability to side step ownership claims regarding rivers, citing the Whanganui River claim where the Waitangi Tribunal recommended that consideration should be given to two possible options: vesting ownership of the river in Maori and requiring written approval from Maori before any water permits could be granted, or providing for Maori membership of the consent authority responible for determining water permit applications. These recommendations were dismissed by the government. Like Sheppard, Ruru also commented on the strength of ss 6-8 of the RMA and observed that they "provide a strong base for Maori to voice their concerns relating to the use of fresh water": [2011] RMT \& P 119 at 125. Ruru also commented on the Waikato-Tainui settlement, including the statutory effect given to the vision and strategy, but noted that "While the Waikato-Tainui Raupatu Claims (Waikato River) Settlement Act 2010 sets a significant standard for co-management between Maori and local authorities, there is much uncertainty as to whether a similar commitment to co-management will be negotiated over any other river": [2011] RMT \& P 119 at 128.

97 Smith, N Agenda for Fresh Water Reform, Speech, Environmental Defence Society Conference, 8 June 2009.

98 Smith, N Agenda for Fresh Water Reform, Speech, Environmental Defence Society Conference, 8 June 2009. 
future national policy direction. The Minister also proffered the following guidance on fresh water allocation: ${ }^{99}$

Any models we decide to use for freshwater allocation need to encourage economic efficiency and growth, and provide for public purposes or community values, including Treaty settlement interests, drinking water, biodiversity protection, the ability to swim and fish, and intrinsic values.

These values need to be identified and addresssed, and weighed up against other values if appropriate, before water for economic purposes is allocated. Once the amount of available water ... is determined, it is appropriate to maximise the economic value of that water through measures which encourage the water to go to its highest value uses.

\section{Land and Water Forum}

Terms of reference for the Land and Water Forum were issued in September 2009, and its report and recommendations were published in September 2010. Following on from the advice proffered by the Minister, the report includes specific recommendations on improving allocation, including, setting "clear limits" to "establish instream flows" in rivers and streams, ground water levels, and the amount of water available for allocation. ${ }^{100}$ The report is clear about the "first in, first served" method of allocating resources under the RMA, and considered that a more efficient allocation method is required by setting a "threshold" to prevent the total amount of water available for allocation being exceeded. ${ }^{101}$ It recommended that such thresholds should be set using "a nationally consistent formula" that recognises "spatial variation" and has the sophistication to derive different numerical

99 Smith, N Agenda for Fresh Water Reform, Speech, Environmental Defence Society Conference, 8 June 2009.

100 Land and Water Forum (2010) Report of the Land and Water Forum: A Fresh Start for Freshwater, para 124, p34.

${ }^{101}$ Land and Water Forum (2010) Report of the Land and Water Forum: A Fresh Start for Freshwater, para 128, p34. 
thresholds for different catchments. ${ }^{102}$ To encourage more efficient allocation the report identified three options that could be considered by government: ${ }^{103}$

- Status quo: changing consent conditions and duration on renewal of water permits.

- Rules in regional water allocation plans.

- Allocating water permits by tender or auction.

The report noted that preparing or changing regional water allocation plans will involve "higher transaction costs" both in relation to the statutory process involved in preparing or changing plans, and administering the permits granted pursuant to the rules in the plan; while tendering or auctioning permits would require further statutory amendment to the RMA. ${ }^{104}$ Placing greater emphasis on regional water allocation plans would also require statutory amendment to the RMA, as the requirement to prepare or change plans would need to be compulsory if this option is to have any success. For example, this point was emphasised by the Minister: ${ }^{105}$

You cannot talk about freshwater without mentioning Canterbury. Last year we took the tough call to replace a stalemated council with commissioners.

A key issue for the Government was, after 19 years of the RMA, the lack of a natural resurces plan to give direction to regional water policy. It is a real credit to the commissioners that in a year the plan is operative with all appeals resolved.

102 Land and Water Forum (2010) Report of the Land and Water Forum: A Fresh Start for Freshwater, para 129, p35.

${ }^{103}$ Land and Water Forum (2010) Report of the Land and Water Forum: A Fresh Start for Freshwater, para 132, pp35-36.

${ }^{104}$ Land and Water Forum (2010) Report of the Land and Water Forum: A Fresh Start for Freshwater, para 132, pp35-36.

${ }^{105}$ Smith, N The Bluegreen Agenda, Speech, Envirinmental Defence Society Conference (3 June 2011) 
Notwithstanding the Minister's view, the Environment Canterbury (Temporary Commissioners and Improved Water Management) Act 2010 has been the subject of critical commentary. For example, Baker noted that the Bill was introduced and passed into law under urgency powers in less than 24 hours during the period 30-31 March 2010, and that the statute had a radical effect on public participation under the RMA by amending statutory process in relation to part heard submissions on policy statements and plans in order to streamline procedure, and by removing the jurisdiction of the Environment Court to decide appeals against decisions on submissions pertaining to the regional plan. In particular, Baker considered that the statute could have had a negative effect on collaborative governance and the outcome of the Land and Water Forum. She concluded: ${ }^{106}$

... these material changes to the implementation of the RMA in Canterbury, combined with the means by which they came into existence, could prove to mark a change of course in public participation and in how the RMA weighs and balances values associated with water bodies. If, at the end of 2010, Canterbury has an integrated, comprehensive, enduring planning framework that strikes a balance supported by the community, then the Act will have succeeded and its fast tracking measures and reduction in public involvement and appeals no doubt be looked on favourably as a template. If, as a result of that framework, the status of the environment and the economy are both advanced then again, it could prove to be a positive turning point. Alternatively, if these objectives do not eventuate, or if the Act triggers a weakening of the LWF's ability to find a way forward, the outcome could be a U-turn back to where we came from.

Statutory intervention in Canterbury was therefore clearly a high risk policy, but it illustrates firmly that streamlining is a key aspect of the RMA reform agenda and that collaborative governance may simply be a component of that wider objective. It also highlights the fact that further statutory amendment, by making regional water allocation

\footnotetext{
106 Baker, M A watershed moment in Canterbury for water management in New
} Zealand August 2010 RMJ 20 at 26. 
plans mandatory, may be preferable to the ad hoc exercise of Ministerial reserve powers.

\section{Greater flexibility: transfer of water permits}

The Land and Water Forum report also emphasised the need for greater flexibility in relation to the transfer of water permits, particularly in over-allocated catchments as a method for allowing access to fresh water resources, and identified three options for consideration by government: ${ }^{107}$

- Transfer without financial consideration.

- Trading without payment for the original permit.

- Trading after payment for the original permit.

The latter option would also require further statutory amendment to the RMA. While the focus on more efficient ways of transferring water permits is laudable, the report failed to address the issue of priority in relation to transfers that was highlighted by the Environment Court decision in Hampton $v$ Hampton, ${ }^{108}$ where the Court questioned whether transfer applications should "have priority over other applications" pertaining to the same resource. It is however clear from s 136(4)(b) of the RMA that applications to transfer water permits are to be processed in the same way as applications for a new permit. The practical effect of this conclusion is that a transfer application will, under the rule in Fleetwing, simply take its place in the queue, and where the water resource is approaching full allocation may be trumped by an application for a new permit filed earlier in time. Clearly, this will impede the ability to establish markets for the transfer of water permits if the purchaser will not have the same priority to

${ }^{107}$ Land and Water Forum (2010) Report of the Land and Water Forum: A Fresh Start for Freshwater, para 138, p37.

${ }^{108}$ C102/08, 12 September 2008. 
access the resource as the vendor. This led Minhinnick to comment with some force that: ${ }^{109}$

Once a resource consent to take water is granted, that resource, and use of it, is allocated for the term of that consent, and the world is on notice of that. To require applicants to start at the beginning again upon transfer seems absurd.

Layton identified six economic lessons that may be relevant for increasing the tradability of water. ${ }^{110}$ The direct lessons from this analysis for water management are that the legal framework whether set out in the RMA or in a regional plan will be critical for the success of the market, that the "first in, first served" rule is not "inconsistent with achieving allocative efficiency" provided that "the rights granted ... are readily tradable", and that separating take and use rights will open the market for parties who "do not currently have a right to use the water". The common denominator which underlies why the current RMA may be unworkable is the enduring policy vacuum. For example, under a devolved framework statute water allocation plans will be critical for establishing viable markets, but they are not in place in all regions. Absent regional water allocation plans the "first in, first served" rule will apply as a default mechanism, but s 136(4)(b) of the RMA will preclude tradability in over-allocated catchments if vendors risk loosing existing rights. Broadening the market to improve outcomes by separating rights to take and use water will be defined by regional rules. This indicates that contrary to the analysis of some commentators, ${ }^{111}$ further statutory amendment is required to both to improve the RMA provisions regarding the transfer of water permits

${ }^{109}$ Minhinnick, D Jumping the Queue? Processing of applications to transfer water permits April 2009 RMJ 26 at 28.

${ }^{110}$ Layton, B Tradable systems for water: Best use and maximising value [2011] RMT \& P 107-117, namely: that markets and legal frameworks are complements, there needs to be clarity about what is being traded, highest value use is relevant when deciding whether or not to trade, tradability should result in allocative efficiency, initial allocations affect wealth distribution - existing rights should not therefore be expropriated without adequate compensation, and broadening the market improves outcomes.

${ }^{111}$ Sheppard, DF Reaching sustainable management of fresh water [2011] RMT \& P 85. 
and to require mandatory preparation of regional water allocation plans and specify their content, or to address fresh water management nationally by using some other policy or planning instrument.

\section{Gazetting the NPS on Freshwater Management}

Finally, the report concluded that more guidance is required from central government via NPS or NES to ensure consistency, and that any transitional arrangements would require careful design to ensure equitable application of the transitional provisions. ${ }^{112}$ The Land and Water Forum has now been asked to provide further recommendations on specific options for reform of fresh water management for the incoming government to consider after the 2011 general election.

In the interim, the Minister decided to gazette the NPS on Freshwater Management, originally prepared under the SWPA, in May 2011. The NPS took effect on 1 July 2011, and specifies an implementation period expiring on 31 December 2030. It adopts a mixed approach to implementation by expressly referring in certain instances to the need for regional councils to prepare or change regional water allocation plans in order to give effect to the NPS, while in other instances having direct effect on local authority decision making. ${ }^{113}$ Two specific policies are required to be included in regional plans with immediate effect in order to provide interim guidance regarding water quality and quantity until regional councils prepare or change regional water allocation plans in order to give effect to the NPS. ${ }^{114}$ In relation to water quantity, the objectives and policies require regional councils to avoid over-allocation and phase out any existing over-allocation, set environmental flows or levels, provide for the efficient allocation of water within such limits, and encourage efficient allocation and use of

112 Land and Water Forum (2010) Report of the Land and Water Forum: A Fresh Start for Freshwater, para 139, p37.

113 National Policy Statement for Freshwater Management 2011, see for example: Policies B1-B3 contrasted with Policies B5-B6, pp8-9.

${ }^{114}$ National Policy Statement for Freshwater Management 2011, Policies A4 and B7, pp7 and 9. 
water by setting out assessment criteria for the transfer of water permits. ${ }^{115}$ It is, however, clear that the NPS is an interim measure and that it is likely to be replaced or amended as further policy work is done by the Land and Water Forum or by central government. ${ }^{116}$ From a critical perspective, the NPS is unlikely to be effective in the short term while regional water allocation plans remain optional, and the date for compliance with the NPS remains fixed in the distant future. For example, taking account of both the NPS compliance period which expires in December 2030 and the period currently required for preparing regional plans under the RMA, it is unlikely that rules would be operative in all regions before 2050, some 49 years after the RMA came into force.

Most recently, the Minister has announced increased funding of $\$ 9.3$ million over six years, for investment in research to map ground water resources, and: ${ }^{117}$

... to support collaborative processes in water resource management with the development of a water wheel framework to set agreed catchment limits for water allocation ... balancing the different competing values and outcomes.

This confirms that further RMA reform is inevitable if the National Government is returned to power after the 2011 general election.

\section{CONCLUSION}

Overall, it is not surprising that issues regarding water allocation continue to recur under the RMA given the absence of any operative NES and where the recently gazetted NPS remains to be implemented.

\footnotetext{
${ }^{115}$ National Policy Statement for Freshwater Management 2011, see for example: Objectives B2-B3 and Policies B1-B3.

${ }^{116}$ Land and Water Forum (2010) Report of the Land and Water Forum: A Fresh Start for Freshwater, pp xiv and 61.

117 Smith N The Bluegreen Agenda, Speech, Environmental Defence Society Conference, 2 June 2011.
} 
For example, Crawford observed in the context of the Central Plains litigation that: ${ }^{118}$

In circumstances where the legislation does not make specific provision for managing priority issues, yet prescribes strict timeframes for decision-making, there is no result that is entirely free of practical difficulties.

Currently, these matters remain to be addressed by phase two of the RMA reform launched by the current National Government in June 2009. The statutory reform process remains ongoing and entered a new phase following release of the report of the Land and Water Forum in September 2010. ${ }^{119}$ The report provided a stakeholder opportunity for policy preparation on a collaborative basis, but due to the timing of the NPS statutory process it has in practice been a lost opportunity to influence water allocation policy in the short-term. However, the Minister's speech at the Environmental Defence Society conference in June 2011 indicates a willingness to build on the recommendations in the report and take a fresh, collaborative approach to water allocation in 2012 as part of the phase two RMA reforms if the National Government is returned to power following the 2011 general election. The onus therefore remains on the government to complete the reform process announced in 2009.

${ }^{118}$ Crawford, J First dibs to the last drop November 2008 RMJ 3 at 6.

${ }^{119}$ Land and Water Forum, Report of the Land and Water Forum: A Fresh Start for Freshwater (September 2010). 